\title{
Escayola reforzada por acción sinérgica entre aditivos del hormigón (fluidificantes, superfluidificantes y aireantes-plastificantes) y fibras de vidrio $E$
}

\author{
Reinforced plaster by means of the synergic action \\ between concrete additives (superfluidifiers, fluidifiers \\ and airing-plasticizers) and $E$ glass fibres
}

\begin{abstract}
M.del RÍOMERINO
Dpto. de Construcciones Arquitectónicas y su Control. E. U. Arquitectura Técnica-U.P. M.

F.HERNÁNDEZOLIVARES Dpto. de Construcción y Tecnología Arquitectónica. E. T.S. Arquitectura-U.P.M.
\end{abstract}

Fecha de recepción: 29-X-99

\section{RESUMEN}

Mediante el análisis de diferentes compuestos (escayola+aditivos +fibras de vidrio E) se pretende demostrar que existe una acción sinérgica entre ciertos aditivos del hormigón (superfluidificantes, fluidificantes y aireantes-plastificantes) y los refuerzos a base de fibras de vidrio $E$, sobre la resistencia a flexión de los materiales compuestos de matriz principal escayola.

\section{SUMMARY}

Through the analysis of the different compounds (plaster+additives $+E$ glass fibres) we pretend to demostrate that a synergic action is present between certain concrete additives (superfluidifiers, fluidifiers, and airingplasticizers) and E glass fibre, on the basis of the flection resistance of plaster matrix based compound materials.

\section{INTRODUCCIÓN}

La compacidad del yeso aumenta cuando se reduce la relación agua/yeso, el problema es que a relaciones de $\mathrm{A} / \mathrm{E}$ menores a 0,8 , la trabajabilidad de la mezcla es muy reducida, sobre todo si se quiere añadir un refuerzo a base de fibras. El objetivo de este estudio es demostrar que a dosificaciones adecuadas de aditivo y fibras, existe una acción sinérgica entre ambos, cuando se añaden a la matriz de escayola, dando lugar a un aumento de la resistencia a flexión de la matriz (llegando a superar los valores de resistencia a flexión obtenidos en compuestos similares realizados sin aditivos o con aditivos y sin refuerzo de fibras), debido principalmente a la posibilidad de reducir el agua en la mezcla, manteniendo la trabajabilidad y mejorando la homogeneidad de la distribución de las fibras.

\section{INTRODUCTION}

Plaster capacity increases when the relation water/ plaster is decreased, the problem is however, that for $A / E$ values smaller than 0.8 , the admixture workability is very reduced and even more when strengthening is to be added using fibres. The aim of this study is to prove that using an adecuate proportion of additive and fibres, a synergic action is produced among them that when applied to a plaster matrix, results in an increase of the matrix flection strength. (it has even exceeded the flection strength values obtained in similar compounds made without additives, or with additives but without reinforcing fibres). This is due mainly to the possibility of reducing the amount of water from the admixture mantaining its workability and improving the fibre distribution homogeneity. 
Se entiende por sinergética una nueva rama de la ciencia, de carácter interdisciplinar, cuyo objetivo son las leyes que gobiernan el comportamiento dinámico de macroestructuras, que, por lo general, se generan en sistemas multi-componentes mediante la interacción entre los elementos que lo componen (1).

\section{MATERIALESUTILIZADOS}

ESCAYOLA. La escayola que se utiliza a lo largo de todo el trabajo es E-35 (2).

ADITIVOS. Aunque estos productos se utilizan de forma usual en la confección de hormigones, llegando a considerarse el cuarto componente del hormigón (3), en la escayola, en general, sólo se incorporan aditivos que actúan sobre los tiempos de fraguado, pero no sobre la compacidad o resistencia mecánica de la misma. Existen trabajos de investigación que desarrollan tesis sobre el refuerzo de la escayola/yeso con este tipo de productos, pero no sobre la mejora conjunta que pueden suponer al añadirse sobre una escayola reforzada con fibra de vidrio $\mathrm{E}(4)$.

Aditivos empleados: recomendados por Bettor y Sika, en base a su mejor adecuación con el yeso/ escayola.

\section{Superfluidificantes:}

- Melment L-10: es un policondensado de melamina $\mathrm{y}$ formaldehido, miscible en agua, de la casa Bettor. Aunque está especialmente recomendado su uso en hormigones, se ha utilizado en ocasiones, como aditivo en pastas de yeso/escayola.

- Sikament FF: aditivo a base de melamina de la casa Sika. No se tienen datos sobre su utilización como aditivo en el yeso o escayola.

Plastificante Forton: dispersión de polímero acrílico con un $51 \%$ de contenido en polímeros sólidos. No se ha encontrado información sobre su comportamiento al añadirse a una matriz de yeso/ escayola.

Plastificante-aireante Sikamor G: de la casa Sika. No se han encontrado referencias sobre su utilización como aditivo del yeso/escayola.

Fibra de vidrio E: el vidrio $\mathrm{E}$, se utiliza en forma de hilos cortados. Los hilos utilizados tienen una longitud de $25 \mathrm{~mm}$, un diámetro de 12 micras y un ensimaje de resina epoxi poliéster. La fibra ha sido proporcionada por Vetrotex.
The term "synergetic" is understood as a new branch of science, with an interdisciplinary character, whose aim is the set of rules which control the dynamic behaviour of macrostructures which are frequently generated in multicomponents systems through the interaction among the different integral elements (1).

\section{MATERIALS USED}

PLASTER. Plaster used in this study is E-35 (2).

ADDITIVES. Although these products are often used in the concrete production, considering it to be the forth concrete component (3), in plaster, in general, only additives which act over the setting time have been included, they have not been used to act over the closeness or the mechanical resistance of plaster. There have been several research studies which have worked on stregthening plaster with this type of materials, but there are none about the joint improvement they could imply when added to E glass fibre strengthened plaster (4).

Additives used: have been recommended by Bettor and Sika, due to their better adecuacy with gypsum/ plaster.

\section{Superfluidifiers:}

- Melment L-10: it is a formaldehyde melanine polycondensate, water mixable from Bettor Co. Although its use has been recommended mainly in concrete, in several occasions it has been used as an additive in plaster/gypsum admixtures.

- Sikament FF: melanine based additive of Sika Co. There is no documentation of its use as additive in gypsum or plaster.

Forton plasticizer: it is a dispersion of acryloid polymer with a $50 \%$ content of solid polymers. Documentation has not been found about its behaviour when added to a plaster/gypsum matrix.

Airing-plasticizer Sikamor G: of Sika. Information has not been found about its use as additive in gypsum/plaster.

E glass fibre: glass $E$, is used in the shape of cut threads. The threads have a lengh of $25 \mathrm{~mm}, a$ diameter of 12 microns, and an epoxy poliester resin oiling. This fibre was provided by Vetrotex. 


\section{PLANDE ENSAYOS}

Para alcanzar el objetivo del estudio se confeccionan series de probetas prismáticas de dimensiones $4 \times 4 \times 16 \mathrm{~cm}$ (tres probetas por serie), según RY-85. Sobre las probetas se realizan ensayos de flexión y compresión y se registran los valores de dureza superficial (Shore C) y pesos a los siete días.

El orden de realización de las probetas y el análisis de las series es el siguiente:

$1^{\circ}$. Se realiza la serie de referencia $8 \mathrm{E}$, escayola sin aditivar con una relación $\mathrm{A} / \mathrm{E}=0,8$ y la serie $6 \mathrm{E}$, escayola sin aditivar con una relación $\mathrm{A} / \mathrm{E}=0,6$, a las que luego se les añade fibras de vidrio $\mathrm{E}$, como refuerzo en proporciones del $1 \%$ (18E y $16 \mathrm{E})$ y $2 \%$ (28E y $26 \mathrm{E})$. Estas series sirven para determinar comparativamente, las posibles mejoras de los compuestos que se estudian (los porcentajes de adición se estiman sobre el peso de la escayola).

$2^{\circ}$. Se realizan series de probetas de escayola con los distintos tipos de aditivos (Melment L-10, Sikament FF, Forton y Sikamor G).

$3^{\circ}$. Se realizan series de probetas de escayola iguales a las del apartado anterior a las que se les adicionan distintos porcentajes de fibra de vidrio $\mathrm{E}$ ( 1 y $2 \%$ ), para determinar el efecto conjunto de los aditivos y las fibras de vidrio $\mathrm{E}$, incorporadas en la matriz de escayola, en base a la comparación de sus valores de resistencia mecánica y dureza superficial con los valores de los mismos en la escayola reforzada con fibras de vidrio $\mathrm{E}$, añadida en las mismas proporciones.

\section{$1^{\circ}$.-SERIES DE REFERENCIA}

Como el principal efecto que tienen todos los aditivos con los que se trabaja es la mejora de la trabajabilidad a relaciones de $\mathrm{A} / \mathrm{E}$ menores a las recomendada en el Pliego RY-85, $\mathrm{A} / \mathrm{E}=0,8$ (serie denominada $8 \mathrm{E}$ ), tomaremos esta serie como referencia, en todas las comparaciones, para sacar conclusiones sobre los compuestos analizados ( $R$. compuesto-R. referencia) (Tabla 1).

\section{$2^{\circ}$.-MATERIAL COMPUESTO: ESCAYOLAY ADITIVOS}

\section{Escayola y superfluidificante Melment L-10}

Se confeccionan series de tres probetas cada una. Series 6, 7 y 8, de escayola aditivada con Melment en un $0,5 \%(8 \mathrm{EM} 0,5$ y $6 \mathrm{EM} 0,5)$ y en un $1 \%$ (6EM1).

Luego, se confeccionan las series anteriores

\section{TESTING PROGRAM}

In order to reach the aim of the study, series of prismatic tests pieces $4 \times 4 \times 16 \mathrm{~cm}$ were made, according to RY-85. With the test pieces, flection strength and compressive strength test were performed, noting down the values for superficial hardness (Shore C) and weights after seven days.

The tests order and the series analysis were the following:

$1^{\circ}$. Reference serie $8 E$ was made using plaster without additives in a $A / E=0.8$ rate, and reference serie $6 E$, using plaster without additives in a $A / E=0.6$ rate. Later $E$ glass fibre as strengthener was added in a proportion of $1 \%$ (18E and $16 E$ ) and $2 \%$ (28E and 26E). These series served to determine by comparison the possible improvements of the studied compounds (the additives percentage is established over the plaster weight).

$2^{\circ}$. Series of plaster test pieces were made with the various additives (Melment L-10, Sikament FF, Forton and Sikamor G).

$3^{\circ}$. Series of plaster tests pieces were made, equal to the previous ones, adding different percentages of $E$ glass fibres ( 1 and $2 \%$ ) in order to determine the joint effect of the additives and the glass fibres incorporated to the plaster matrix. Then, we compared the mechanical resistance and superficial hardness values with the ones obtained from the plaster strengthened with $E$ glass fibres, added in the same proportion.

\section{$1^{\circ}$--REFERENCESERIES}

(Since the main effect of all the additives used in this research is the improvement of workability at a $A / E$ rate smaller than the recommended in $R Y-85, A / E=0.8$ (serie called $8 E$ ), we will take this series as reference in all the comparisons with the analyzed compounds. (R. compound-R. reference) (Table 1).

\section{2'.-COMPOUND MATERIAL:PLASTER AND ADDITIVES}

\section{Plaster and Melment L-10 superfluidifier}

Series of three test pieces are produced. Series 6, 7 and 8 using plaster additivated with Melment in a $0.5 \%$ proportion $(8 E M 0,5$ y $6 E M 0,5)$ and in a $1 \%$ (6EM1). Series $9,10,11$ and 12 are the previous 
reforzadas con fibras de vidrio $\mathrm{E}$ en un 1\%,(16EM0,5, $16 \mathrm{EM} 1$ ), y un $2 \%$ de adición (26EM1 y 26EM0,5), series $9,10,11$ y 12 (Tabla 2 ).

\section{Resistencia mecánica de la escayola con Melment}

\section{Resistencia a flexión}

En las series de escayola y Melment sin refuerzos de fibra, se produce una disminución de la resistencia a flexión con respecto a la escayola sin aditivar y la misma relación $\mathrm{A} / \mathrm{E}$, pero si la resistencia a flexión se compara con la serie de referencia el incremento de la misma para una adición del $1 \%$ es positivo. Cuando se series strengthened with $E$ glass fibres in a $1 \%$ proportion (16EM0,5, 16EMI), and in a $2 \%$ of reinforcement (26EM1 y 26EM0,5) (Table 2).

\section{Plaster with Melment mechanical strength}

\section{Flection resistance}

In the series of plaster and Melment without fibre strengthening, a decrease in the flection resistance is produced compared to plaster without additives and the same relation $A / E$. But if the flection resistance is compared to the reference series, the increase for an addition of $1 \%$ or when $E$ glass fibres are added is

\section{TABLA 1 (TABLE 1)}

Resultados de los ensayos sobre probetas de escayola, con y sin fibras de vidrio $\mathrm{E}$

(Test results performed on plaster test pieces, with and without $E$ glass fibres)

\begin{tabular}{||c|c|c|c|c|c||}
\hline Serie & $\begin{array}{c}\text { Denominación } \\
(\text { Name })\end{array}$ & $\begin{array}{c}\text { Peso } 7^{\circ} \text { día }(\mathrm{g}) \\
\text { Weight day } 7 \\
(g))\end{array}$ & $\begin{array}{c}\text { R. Flexión }\left(\mathrm{kp} / \mathrm{cm}^{2}\right) \\
\left.\text { (Flection } R .\left(\mathrm{kp} / \mathrm{cm}^{2}\right)\right)\end{array}$ & $\begin{array}{c}\text { R. Compresión }\left(\mathrm{kp} / \mathrm{cm}^{2}\right) \\
\left(\text { Compression } R .\left(\mathrm{kp} / \mathrm{cm}^{2}\right)\right)\end{array}$ & $\begin{array}{c}\text { Shore } \\
\mathrm{C}\end{array}$ \\
\hline 0 & $8 \mathrm{E}$ & 243 & 33 & 58 & 67,5 \\
\hline 1 & $18 \mathrm{E}$ & 254,27 & 32,76 & 63,05 & 65 \\
\hline 2 & $28 \mathrm{E}$ & 254,47 & 48 & 32,70 & 63 \\
\hline 3 & $6 \mathrm{E}$ & 288 & 52,16 & 98,5 & 80 \\
\hline 4 & $16 \mathrm{E}$ & 290 & 54,16 & 110,28 & 75 \\
\hline 5 & $26 \mathrm{E}$ & 292 & 60 & 85 & 73 \\
\hline
\end{tabular}

TABLA 2 (TABLE 2)

Resultados medios de los ensayos sobre las probetas de escayola y Melment L-10, con y sin fibras de vidrio E (Average test results performed on plaster and Melment L-10, with test and without $E$ glass fibres)

\begin{tabular}{|c|c|c|c|c|c|}
\hline Serie & $\begin{array}{l}\text { Denominación } \\
\text { (Name) }\end{array}$ & $\begin{array}{c}\text { Peso } 7^{\circ} \text { día (g) } \\
\text { Weight day } 7 \\
(\mathrm{~g})) \\
\end{array}$ & $\begin{array}{l}\text { R. Flexión R. }\left(\mathrm{kp} / \mathrm{cm}^{2}\right) \\
\left(\text { Flection } R \cdot\left(\mathrm{kp} / \mathrm{cm}^{2}\right)\right)\end{array}$ & $\begin{array}{l}\text { R. Compresión }\left(\mathrm{kp} / \mathrm{cm}^{2}\right) \\
\left(\text { Compression } R .\left(\mathrm{kp} / \mathrm{cm}^{2}\right)\right)\end{array}$ & $\begin{array}{l}\text { Shore } \\
\text { C }\end{array}$ \\
\hline 6 & $8 \mathrm{EM} 0,5$ & 253 & 27 & 40 & 73,66 \\
\hline 7 & $6 \mathrm{EM} 0,5$ & 313,26 & 24,83 & 77,94 & 87,5 \\
\hline 8 & 6EM1 & 299,86 & 39,33 & 65,41 & 86 \\
\hline 9 & 16EM0,5 & 312,86 & 32 & 79,04 & 85 \\
\hline 10 & $26 \mathrm{EM} 0,5$ & 303,16 & 46,33 & 64,79 & 83 \\
\hline 11 & 16EM1 & 318,2 & 59,25 & 55,31 & 87 \\
\hline 12 & 26EM1 & 299,8 & 61,66 & 43,33 & 84 \\
\hline
\end{tabular}



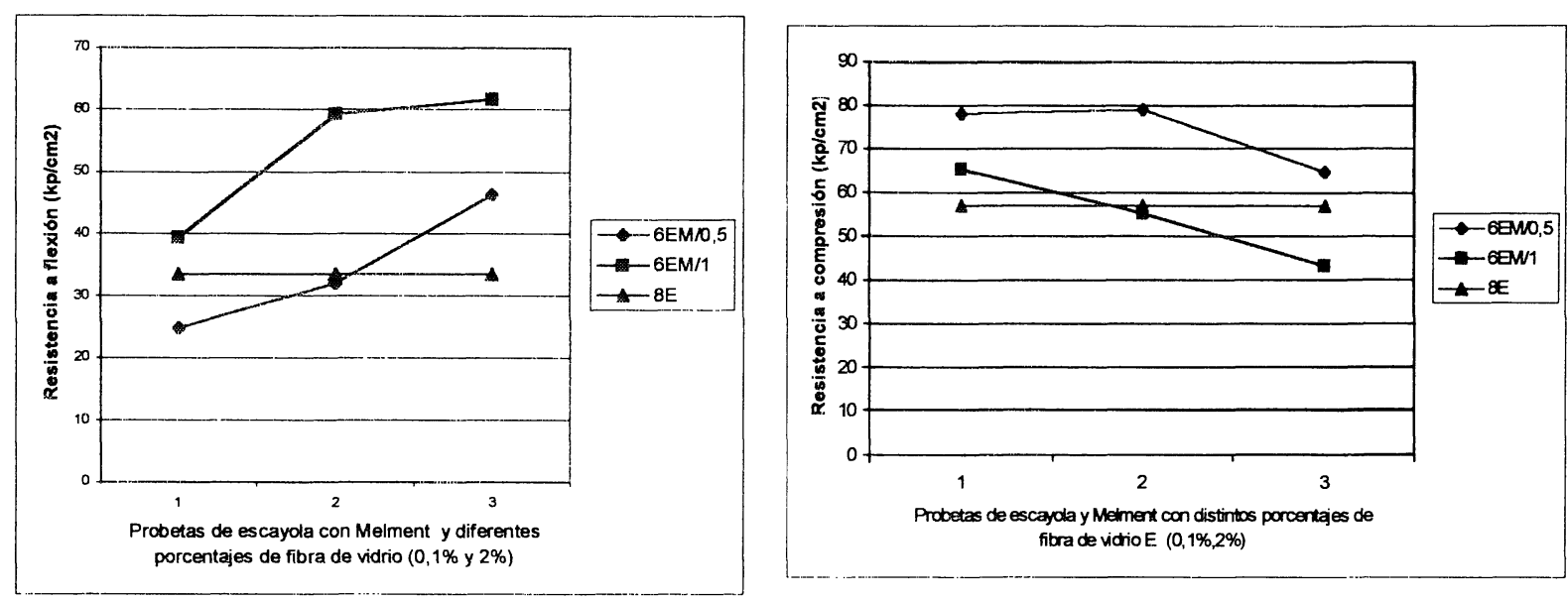

Gráficas 1 y 2.- Resistencia a flexión y compresión de las series de escayola con Melment con y sin fibras de vidrio E.

Graphs 1 and 2.- Flection resistance and compressive strength of the plaster and Melment series, with and without E glass fibres.

añaden fibras de vidrio $E$, se produce un incremento en la resistencia, en todos los casos, con respecto a la serie de referencia (8E), y en las series 11 y 12 , confirmando una acción sinérgica, se produce un aumento de la resistencia con respecto a las series de referencia 4 y 5 , de escayola reforzada (Gráfica 1 ).

\section{Resistencia a compresión}

La resistencia a compresión disminuye con la adición del Melment, frente a la escayola sin aditivar con la misma relación $\mathrm{A} / \mathrm{E}$, pero aumenta de forma considerable con respecto a la serie $8 \mathrm{E}$. Por otra parte, a un aumento de la cantidad de aditivo, corresponden menores valores de la resistencia a compresión, al contrario de lo que sucedía en la resistencia a flexión. Cuando a los compuestos se les añade un refuerzo de fibras de vidrio, se produce una disminución de la resistencia a compresión, mayor, con mayores porcentajes de adición de la misma (Gráfica 2).

\section{Escayola aditivada con superfluidificante Sikament FF}

Se confeccionan las series 13,14 y 15 : escayola aditivada con Sikament FF en un 0,5\% (8ESK0,5, $6 \mathrm{ESK} 0,5)$ y en un $1 \%(6 \mathrm{ESK} 1)$. Después se realizan las series $16,17,18$ y 19 que son las series anteriores reforzadas con fibras de vidrio $\mathrm{E}$ en un $1 \%$ (16ESK0,5, $16 \mathrm{ESK} 1)$, y un $2 \%$ (26ESK1 y $26 \mathrm{ESK} 0,5)$ (Tabla 3 ).

\section{Resistencia mecánica de la escayola con Sikament}

\section{Resistencia a flexión}

La escayola con este producto, disminuye su resistencia a flexión con respecto a compuestos con la positive. When E glass fibres are added, there is an increase in resistance produced in relation to the reference series (8E) in every case. In the 11 and 12 series, an increase in resistance is produced, in relation to the strengthened plaster reference series 4 and 5 thus proving the synergic action (Graph 1).

\section{Compressive strength}

Resistance to compression decreases when Melment is added as opposed to non-additived plaster with the same $A / E$ proportion. However, compressive strength increases greatly in relation to the reference series. On the other hand, the greater the increase of additives, the lower the compressive strength values, exactly the opposite of what occurred with the flection resistance. When a glass fibre strengthening is added to the compounds, a decrease in compressive strength is produced, which is greater with higher additive percentages (Graph 2).

\section{Superfluidifier Sikament FF additivated plaster}

Series 13, 14 and 15 were produced using 0.5\% superfluidifier Sikament FF additivated plaster (8ESK0,5, 6 ESK0,5) and 1\% (6ESK1). Later on, series 16,17, 18 and 19 were developed, corresponding to the previous series but with E glass fibres strengthening in a $1 \%$ (16ESK0,5, 16ESK1), and in a $2 \%(26 E S K 1$ y 26ESK0,5) (Table 3).

\section{Sikament plaster mechanical resistance}

\section{Flection resistance}

Flection resistance increases in Sikament FF plaster when there is an increase in the superfluidizer proportion as 
TABLA 3 (TABLE 3)

Resultados de los ensayos sobre probetas de escayola y Sikament FF, con y sin fibras de vidrio E (Test results performed on Sikament FF plaster test pieces, with and with and without $E$ glass fibres)

\begin{tabular}{||c|c|c|c|c|c||}
\hline Serie & $\begin{array}{c}\text { Denominación } \\
(\text { Name })\end{array}$ & $\begin{array}{c}\text { Peso 70 dia }(\mathrm{g}) \\
(\text { Weight day 7 } \\
(\mathrm{g}))\end{array}$ & $\begin{array}{c}\text { R. Flexión }\left(\mathrm{kp} / \mathrm{cm}^{2}\right) \\
\left(\text { Flection } R .\left(\mathrm{kp} / \mathrm{cm}^{2}\right)\right)\end{array}$ & $\begin{array}{c}\text { R. compresion }\left(\mathrm{kp} / \mathrm{cm}^{2}\right) \\
\left(\text { Compression } R .\left(\mathrm{kp} / \mathrm{cm}^{2}\right)\right)\end{array}$ & $\begin{array}{c}\text { Shore } \\
\mathrm{C}\end{array}$ \\
\hline 13 & $8 \mathrm{ESK} 0,5$ & 253,3 & 26,58 & 47,5 & 77 \\
\hline 14 & $6 \mathrm{ESK} 0,5$ & 294 & 40 & 73,56 & 90 \\
\hline 15 & $6 \mathrm{ESK} 1$ & 283,86 & 48,33 & 51,97 & 81,66 \\
\hline 16 & $16 \mathrm{ESK} 0,5$ & 295 & 60,08 & 46,81 & 90 \\
\hline 17 & $26 \mathrm{ESK} 0,5$ & 299 & 79,45 & 45,31 & 90 \\
\hline 18 & $16 \mathrm{ESK} 1$ & 296,8 & 51 & 44,37 & 87 \\
\hline 19 & $26 \mathrm{ESK} 1$ & 304,4 & 85 & 56,24 & 87 \\
\hline
\end{tabular}

misma relación $\mathrm{A} / \mathrm{E}$, aunque aumenta su resistencia con respecto a la serie de referencia $(8 \mathrm{E})$. Esta resistencia se incrementa al aumentar el porcentaje de aditivo, así como al incorporar fibras de vidrio, consiguiendo para porcentajes de adición de fibra de un $2 \%$ superar la resistencia a flexión del mismo material pero sin Sikament $\mathrm{FF}$, verificándose la existencia de una acción sinérgica entre el aditivo, la fibra y la escayola (Gráfica 3).

\section{Resistencia a compresión}

En todos los casos se reducen los valores obtenidos con las series de la misma relación $\mathrm{A} / \mathrm{E}$, aunque al reducir el agua de amasado se mejoran los valores obtenidos en la serie (8E). Por otra parte a un aumento de la adición del Superfluidificante, como se observa en la gráfica 4, corresponden disminuciones de la resistencia a compresión, al contrario de lo que sucedía en la resistencia a flexión. Por otro lado, al añadir fibras de vidrio se produce una reducción de los valores obtenidos sin refuerzo de fibras.

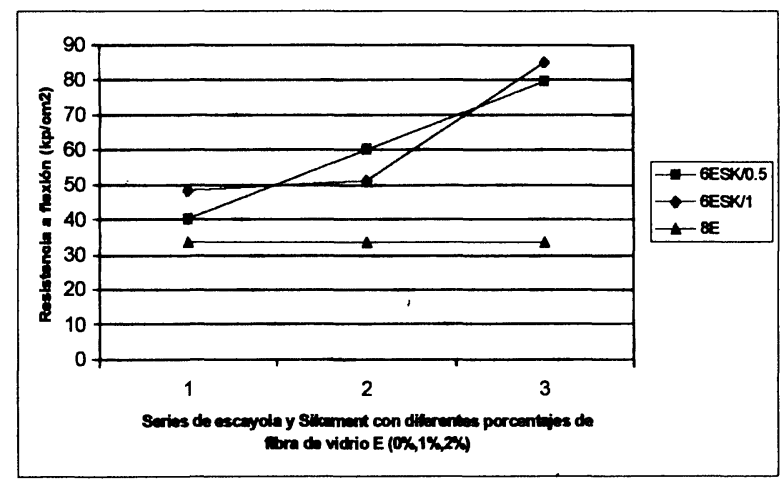

well as when glass fibres are incorporated, the result for fibre additive proportion of $2 \%$ surpasses the flection resistance of the same material without Sikament $F F$, proving the existance of a synergic action between the additive, the fibre and the plaster (Graph 3).

\section{Compressive resistance}

In all cases studied, there is a reduction of the obtained values on the one hand, within series of the same $A / E$ relation, although the obtained values improve in the $8 E$ series, when the amount of water is reduced in the mixture. On the other hand, the greater the addition of superfluidifier, as shown in graph 4, the lower the compressive strength, inversely to what occurred with the flection resistance. Moreover, when glass fibres are added a reduction of the obtained values of non strengthened fibres is produced.

Gráficas 3 y 4.- Resistencia a flexión y compresión de las series de escayola y Sikament, con y sin fibras de vidrio E.

Graphs 3 and 4.- Flection resistance and compressive strength of the Sikament plaster series, with and without E glass fibres. 


\section{Escayola con fluidificante Forton}

Se confeccionan las series 20,21 y 22 : escayola aditivada con Forton en un 3\% (8EF3, 6EF3) y en un $5 \%$ (6EF5). Luego se confeccionan las series 23,24 , 25 y 26: iguales que las anteriores pero reforzadas con fibras de vidrio $\mathrm{E}$ en un $1 \%$ (16EF3, 16EF5), y un $2 \%$ (26EF3 y 26EF5) (Tabla 4$)$.

\section{Resistencia mecánica de la escayola con Forton}

Resistencia a flexión

Al reducir la relación de $\mathrm{A} / \mathrm{E}$ a 0,6 , se produce un aumento de la resistencia a flexión con respecto a la escayola de referencia (8E). Este aumento, para dosificaciones del aditivo del 5\%, es mayor cuando se añaden fibras de vidrio $\mathrm{E}$ como refuerzo, superándose los valores obtenidos en las series 4 y 5 , verificándose la acción sinérgica. En cambio para adiciones de Forton del $3 \%$, con respecto a la serie $(8 \mathrm{E})$, se obtiene un aumento importante en los valores de resistencia similar con y sin refuerzo de fibra de vidrio E (Gráfica 5).

Resistencia a compresión

Como se observa en la gráfica 6, al aumentar la adición de fluidificante, disminuyen los valores de la resistencia a compresión, que, en todo caso, son menores que en las series de referencia con la misma relación $\mathrm{A} / \mathrm{E}$. Al añadir fibras a los compuestos de escayola y Forton, disminuyen los valores obtenidos en los ensayos de los compuestos sin refuerzo.

\section{Forton fluidifier plaster}

Series 20, 21 and 22 Forton additivated plaster in $3 \%(8 E F 3,6 E F 3)$ proportion and in a $5 \%(6 E F 5)$ are made. After it, series 23, 24, 25 and 26 were performed in the same way that the previous ones but strengthened with E glass fibres in 1\% (16EF3, $16 E F 5)$, and in $2 \%$ (26EF3 y 26EF5) (Table 4).

\section{Forton plaster mechanical resistance}

\section{Flection resistance}

When the $A / E$ relation is reduced to 0.6 , an increase in flection resistance is produced in relation to the plaster reference $8 E$. This increase, for amounts of additive of $5 \%$, is greater, when E glass fibres are added as strengthener, even improving the obtained values of series 4 and 5, confirming therefore the synergic action. For 3\% Forton addition, an important similar increase in the resistance values is obtained in plaster with or without $E$ glass fibres (Graph 5).

\section{Compressive strength}

As can be seen in graph 6, the greater the addition of fluidifier, the greater the decrease in the compressive strength values. For fiber strengtening, there is a decrease in compressive strength especially visible in the $6 E F 3$ series.

TABLA 4 (TABLE 4)

Resultados medios de los ensayos sobre las probetas de escayola y Forton, con y sin fibras de vidrio $\mathrm{E}$ (Average test results performed on Forton plaster test pieces, with and without $E$ glass fibres)

\begin{tabular}{|c|c|c|c|c|c||}
\hline Serie & $\begin{array}{c}\text { Denominación } \\
(\text { Name })\end{array}$ & $\begin{array}{c}\text { Peso 7o día (g) } \\
\text { Weight day } 7 \\
(g))\end{array}$ & $\begin{array}{c}\text { R. Flexión }\left(\mathrm{kp} / \mathrm{cm}^{2}\right) \\
\left(\text { Flection } R .\left(\mathrm{kp} / \mathrm{cm}^{2}\right)\right.\end{array}$ & $\begin{array}{c}\text { R. Compresión }\left(\mathrm{kp} / \mathrm{cm}^{2}\right) \\
\left(\text { Compression } R .\left(\mathrm{kp} / \mathrm{cm}^{2}\right)\right)\end{array}$ & $\begin{array}{c}\text { Shore } \\
\mathrm{C}\end{array}$ \\
\hline 20 & $8 \mathrm{EF3}$ & 243,3 & 31 & 35,19 & 72 \\
\hline 21 & $6 \mathrm{EF3}$ & 290 & 50.5 & 64,68 & 84 \\
\hline 22 & $6 \mathrm{EF5}$ & 284,6 & 47,16 & 52,08 & 83,6 \\
\hline 23 & $16 \mathrm{EF3}$ & 287,4 & 49,5 & 59,8 & 86,5 \\
\hline 24 & $26 \mathrm{EF3}$ & 284,9 & 48 & 59,16 & 84 \\
\hline 25 & $16 \mathrm{EF5}$ & 288,33 & 57 & 51,03 & 86 \\
\hline 26 & $26 \mathrm{EF5}$ & 274,4 & 50,20 & 85,5 \\
\hline
\end{tabular}



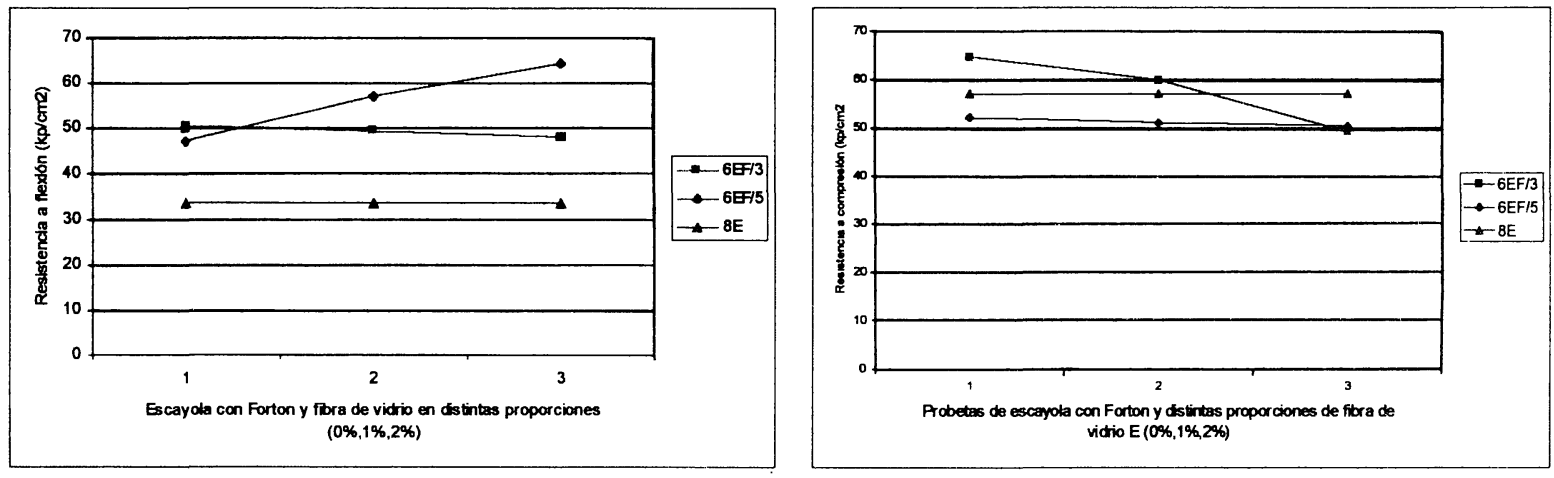

Gráficas 5 y 6.- Resistencia a flexión y compresión de las series de escayola y Forton, con y sin fibras de vidrio E.

Graphs 5 and 6.- Flection resistance and compressive strength of Forton plaster series, with and without E glass fibres.

\section{Escayola aditivada con plastificante-aireante Sikamor G}

Se confeccionan las series 27,28 y 29 , de escayola aditivada con Sikamor G, en un $0,5 \%$ (8ESKG0.5, $6 \mathrm{ESKG} 0.5)$ y en un $1 \%$ (6ESKG1) y las series anteriores reforzadas con fibras de vidrio $\mathrm{E}(30,31$, 32 y 33 ) en un $1 \%$ (16ESK0.5, 16ESK 1$)$, y un $2 \%$ de refuerzo (26ESK1 y $26 \mathrm{ESK} 0.5)$.

\section{Resistencia mecánica de la escayola con Sikamor G}

\section{Resistencia a flexión}

Se produce una disminución de la resistencia a flexión con respecto a la escayola sin aditivar y la misma relación $\mathrm{A} / \mathrm{E}$, pero en las series realizadas con una relación $\mathrm{A} / \mathrm{E}=0,6$, hay una mejora, en los valores de resistencia, con respecto a la serie de referencia de hasta un $51 \%$, muy similar para las dos dosificaciones de aditivo analizadas. Con refuerzo de fibra de vidrio $\mathrm{E}$, se mejoran los valores de resistencia, incluso con un refuerzo del $2 \%$ de fibra, se consiguen mejorar los valores del mismo compuesto sin aditivo hasta en un 5\% (Tabla 5) (Gráfica 7).

\section{Resistencia a compresión}

Al añadir Sikamor $\mathrm{G}$, disminuyen los valores obtenidos en las series de referencia con la misma relación $\mathrm{A} / \mathrm{E}$. Además, a un aumento de la adición, corresponden mayores disminuciones de la resistencia a compresión.

El refuerzo con fibra de vidrio $\mathrm{E}$, disminuye de forma importante los valores de la resistencia obtenidos en los compuestos sin reforzar (Gráfica 8).

\section{Sikamor $G$ airing-plastizer plaster}

Series 27, 28 and 29, are produced with additivated plaster with Sikamor $G$, in a $0.5 \%$ proportion (8ESKG0.5, 6ESKG0.5) and in a $1 \%(6 E S K G)$ and the same series strengthened with $E$ glass fibres (30, 31, 32 and 33$)$ in a 1\% proportion (16ESK0.5, 16ESK1), and in a $2 \%$ (26ESK1 and 26ESK0.5).

\section{Sikamor G plaster mechanical resistance}

\section{Flection resistance}

$A$ decrease in flection resistance is produced in relation to non-additivated plaster with the same $A / E$ relation, but there is an improvement when compared to the reference series of up to $51 \%$ and very similar for the two samples of additive proportion studies, with and without $E$ glass fibre strengthening. With the $E$ glass fibre strengthening, the resistance values improve. Even with a $2 \%$ addition of fibre, the values of the same compound without additive can be improved up to a 5\% (Table 5) (Graph 7).

\section{Compressive strength}

In this case, the greater the Sikamor $G$ addition, the greater the decrease of compressive strength.

The E glass fibre strengthening decreases greatly the values of compressive strength obtained in nonadditivated compounds (Graph 8). 
TABLA 5 (TABLE 5)

Resultados medios de los ensayos sobre las probetas de escayola y Sikamor G, con y sin fibras de vidrio E

(Average test results performed on Sikamor $G$ plaster test pieces, with and without $E$ glass fibre)

\begin{tabular}{|c|c|c|c|c|c|}
\hline Serie & $\begin{array}{l}\text { Denominación } \\
\text { (Name) }\end{array}$ & $\begin{array}{c}\text { Peso } 7^{\circ} \text { día }(\mathrm{g}) \\
\text { (Weight day } 7 \\
(\mathrm{~g}))\end{array}$ & $\begin{array}{l}\text { R. Flexión }\left(\mathrm{kp} / \mathrm{cm}^{2}\right) \\
\text { (Flection } R .\left(\mathrm{kp} / \mathrm{cm}^{2}\right)\end{array}$ & $\begin{array}{l}\text { R. compresión }\left(\mathrm{kp} / \mathrm{cm}^{2}\right) \\
\left(\text { Compression } R \cdot\left(\mathrm{kp} / \mathrm{cm}^{2}\right)\right)\end{array}$ & $\begin{array}{c}\text { Shore } \\
\text { C }\end{array}$ \\
\hline 27 & 8 ESKG0,5 & 243,6 & 25,5 & 42,8 & 73 \\
\hline 28 & $6 \mathrm{ESKG0,5}$ & 282 & 49,83 & 64,15 & 85 \\
\hline 29 & 6ESKG1 & 296,4 & 47,16 & 51,66 & 84 \\
\hline 30 & 16ESKG0,5 & 288 & 51 & 33,73 & 85 \\
\hline 31 & 26ESKG0,5 & 288 & 66 & 34,8 & 85 \\
\hline 32 & 16ESKG1 & 293 & 46,5 & 46,71 & 84 \\
\hline 33 & 26ESKG1 & 294,6 & 63 & 44,37 & 83 \\
\hline
\end{tabular}
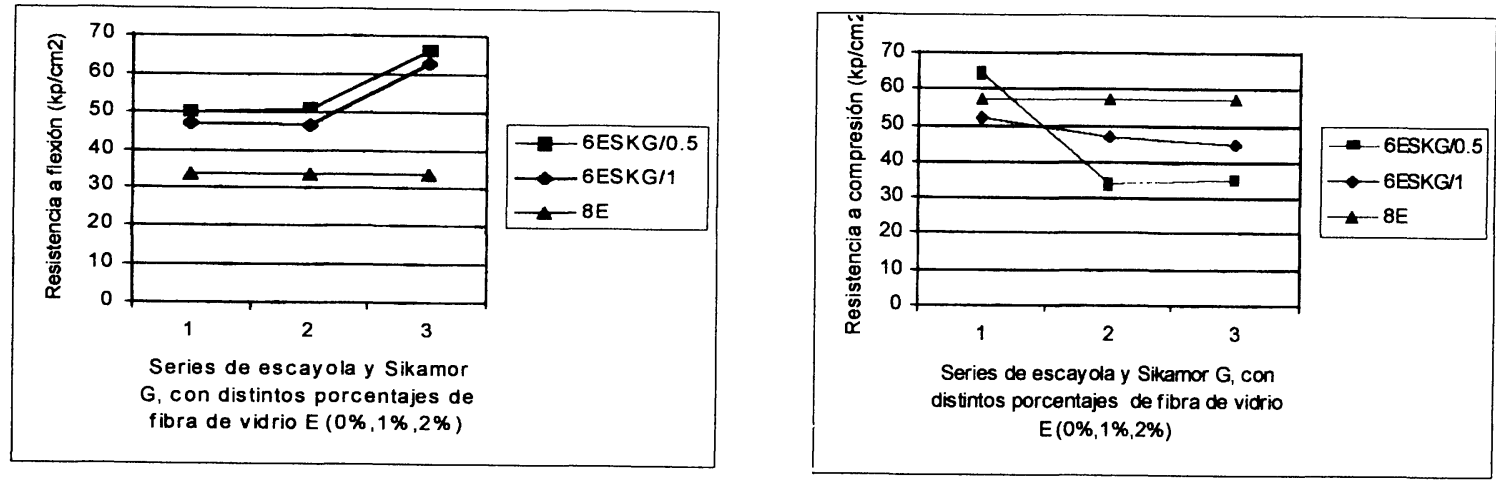

Gráficas 7 y 8.- Resistencia a flexión y compresión de las series de escayola y Sikamor G, con y sin fibras de vidrio E.

Graphs 7 and 8.- Flection resistance and compressive strength of Sikamor G plaster series, with and without E glass fibres.

\section{CONCLUSIONES SOBRE LA ADICIÓN DE SUPERFLUIDIFICANTES, FLUIDIFICANTES Y PLASTIFICANTES A LA ESCAYOLA Y REFUERZO DE FIBRA DE VIDRIO E}

En la Tabla 6, se muestra el conjunto de las series estudiadas con los incrementos (negativos o positivos) que experimentan con respecto a la escayola sin aditivar, serie de referencia (8E), en los ensayos que se han realizado.

En general:

- Los pesos de las probetas realizadas con escayola, aditivos y fibras de vidrio, son similares a los de la escayola sin aditivar con la misma relación $\mathrm{A} / \mathrm{E}$. No hay, por tanto, influencia en el peso.

\section{CONCLUSIONS ON THE ADDITION OF SUPERFLUIDIFIERS, FLUIDIFIERS AND AIRING-PLASTICIZER TO PLASTER AND E GLASS FIBRE STRENGTHENING}

On Table 6, the collection of the studied series is shown with the corresponding increases (negative or positive) experienced in relation to non-additivated plaster, reference serie (8E), in the different tests performed.

In general

- The weights of the test pieces produced with plaster and different percentages of the studied additives as well as glass fibres, are similar to the ones of nonadditivated plaster with the same A/E proportion. 
TABLA 6 (TABLE 6)

Relación de incrementos de resistencias mecánicas y durezas superficiales (Compuesto-Referencia)

(List of mechanical resistance and superficial hardness hardness increases (Compound-Reference)

\begin{tabular}{|c|c|c|c|c|c|}
\hline Serie & $\begin{array}{l}\text { Denominación } \\
\text { (Name) }\end{array}$ & $\begin{array}{l}\text { Tipo aditivo } \\
\text { (Additive type) }\end{array}$ & $\begin{array}{l}\Delta \text { R. Flexión }(\%) \\
\Delta \text { Flection } R .(\%)\end{array}$ & $\begin{array}{c}\Delta \mathrm{R} \text {. Compresión }(\%) \\
(\Delta \text { Compressive } R .(\%))\end{array}$ & $\begin{array}{c}\Delta \\
\text { Shore } \\
\text { C }\end{array}$ \\
\hline 6 & $8 \mathrm{EM} 0,5$ & \multirow[t]{3}{*}{ Melment } & $-18,18$ & -31 & $+6,16$ \\
\hline 7 & $6 \mathrm{EM} 0,5$ & & $-24,75$ & $+34,37$ & +20 \\
\hline 8 & 6EM1 & & $+19,18$ & $+12,77$ & $+18,5$ \\
\hline 9 & $16 \mathrm{EM} 0,5$ & \multirow[t]{4}{*}{ Melment } & $-3,03$ & $+36,27$ & $+17,5$ \\
\hline 10 & $26 \mathrm{EM} 0,5$ & & $+40,39$ & $+11,70$ & $+15,5$ \\
\hline 11 & $16 \mathrm{EM} 1$ & & $+79,54$ & $-4,63$ & +19.5 \\
\hline 12 & $26 \mathrm{EM} 1$ & & $+86,84$ & $-25,29$ & 16,5 \\
\hline 13 & $8 \mathrm{ESK}, 0,5$ & \multirow[t]{3}{*}{ Sikament FF } & $-19,45$ & $-16,66$ & $+9,5$ \\
\hline 14 & $6 \mathrm{ESK} 0,5$ & & $+21,21$ & $+26,82$ & +22.5 \\
\hline 15 & 6ESK1 & & $+46,45$ & $-10,39$ & $+15,16$ \\
\hline 16 & 16ESK0,5 & \multirow[t]{4}{*}{ Sikament FF } & $+82,06$ & $-19,29$ & +22.5 \\
\hline 17 & $26 \mathrm{ESK} 0,5$ & & $+140,75$ & $-21,87$ & $+22,5$ \\
\hline 18 & 16ESK1 & & $+54,54$ & $-23,5$ & $+19,5$ \\
\hline 19 & 26ESK1 & & $+157,57$ & $-3,03$ & +19.5 \\
\hline 20 & $8 \mathrm{EF} 3$ & \multirow[t]{3}{*}{ Forton } & $-6,06$ & $-39,32$ & $+4,5$ \\
\hline 21 & $6 \mathrm{EF} 3$ & & $+53,03$ & $+11,51$ & $+16,5$ \\
\hline 22 & $6 \mathrm{EF} 5$ & & $+42,90$ & $-10,20$ & $+16,1$ \\
\hline 23 & $16 \mathrm{EF} 3$ & \multirow[t]{4}{*}{ Forton } & +50 & $+3,10$ & +19 \\
\hline 24 & 26EF3 & & $\begin{array}{r}+45,45 \\
\end{array}$ & $-15,24$ & $+16,5$ \\
\hline 25 & $16 \mathrm{EF} 5$ & & $+72,72$ & $-12,01$ & +18.5 \\
\hline 26 & 26EF5 & & $+94,93$ & $-13,44$ & +19 \\
\hline 27 & 8ESKG0,5 & \multirow[t]{3}{*}{ Sikamor G } & $-31,8$ & $-26,2$ & $+6,5$ \\
\hline 28 & $6 \mathrm{ESKG0,5}$ & & +51 & $+10,60$ & +17.5 \\
\hline 29 & 6ESKG1 & & $+42,90$ & $+10,93$ & $+16,5$ \\
\hline 30 & $16 \mathrm{ESKG} 0,5$ & \multirow[t]{4}{*}{ Sikamor G } & $+54,54$ & $-41,84$ & +17.5 \\
\hline 31 & 26ESKG0,5 & & +100 & -40 & +17.5 \\
\hline 32 & 16ESKG1 & & $+40,90$ & $-19,46$ & $+16,5$ \\
\hline 33 & 26ESKG1 & & $+90,90$ & $-23,50$ & $+15,5$ \\
\hline
\end{tabular}

- Con los superfluidificantes y aireantes se consigue mejorar la trabajabilidad de la mezcla a menor relación $\mathrm{A} / \mathrm{E}$. Se ha trabajado con relaciones de $\mathrm{A} / \mathrm{E}=0,6$, pero los compuestos admiten reducciones de agua superiores.
- There is therefore no influence on the weight, and with the use of superfluidifiers and aeraters the workability of the admixture is improved even at a smaller $A / E$ relation. 
- En todos los casos estudiados se consiguen importantes aumentos de la dureza superficial del material, incluso con respecto a las series de referencia de igual relación $\mathrm{A} / \mathrm{E}$.

- Al añadir los aditivos se observa una importante reducción en los valores de resistencia a flexión y a compresión de las series ensayadas, con respecto a los valores de la escayola sin aditivar con la misma relación $\mathrm{A} / \mathrm{E}$, pero no con respecto a la serie de referencia $(8 \mathrm{E})$.

- Por último, a dosificaciones adecuadas de aditivo y refuerzo de fibra de vidrio $\mathrm{E}$, se consigue una importante mejora en la resistencia a flexión superando a la de los compuestos escayola+aditivo o escayola+fibras de vidrio E, comprobándose la existencia de una acción sinérgica entre los aditivos y la fibra de vidrio $\mathrm{E}$.

\section{Conclusiones sobre la adición de superfluidificantes en la escayola}

Facilita la reducción de agua manteniendo la trabajabilidad. Se ha trabajado con relaciones de $\mathrm{A} / \mathrm{E}=0,6$, pero los compuestos admiten reducciones de agua superiores.

Para conseguir mejoras de la resistencia mecánica en general, se recomienda la adición de Melment L-10 en un $1 \%$ o de Sikament FF en un $0,5 \%$, ambos sin refuerzo de fibras.

Para conseguir un importante aumento de la resistencia a flexión, se recomienda el refuerzo con fibra de vidrio $\mathrm{E}$ y dosificaciones del 1\% de Melment L-10 y del 0,5 o 1\% de Sikament FF. Destacándose las series 17 y 19 , con las que se consiguen incrementos de resistencia a flexión considerables, con.respecto a la serie $8 \mathrm{E}(140-157 \%)$.

\section{Conclusiónes sobre la adición de fluidificantes en la escayola}

La utilización de fluidificantes como aditivo en el yeso/escayola, no facilita la reducción de $\mathrm{A} / \mathrm{E}$, para la misma trabajabilidad.

Por otra parte los inconvenientes fundamentales de este aditivo son su coste superior y su mal comportamiento al fuego.

Para mejorar en general la resistencia mecánica, se recomiendan adiciones del $3 \%$ de aditivo.
- In all the studied cases remarkable increases of the superficial hardness of material are achieved.

- When the additives are included an important reduction of the flection and compressive resistance values is perceived in the different studied series in relation to the values of non-additivated plaster with the same $A / E$ relation, but not so in relation to the reference series ( $8 E$ ).

- It can be noted also that with the adequate quantity of additive and $E$ glass fibre, a remarkable improvement in flection resistance (greater than that of additive+plaster or plaster $+E$ glass fibres) and in the compound toughness has been achieved, preventing the sudden breaking of the test pieces, once again proving the existance of the synergic action among the additives and the E glass fibre.

\section{Conclusions on the addition of superfluidifiers to plaster}

It makes the water reduction easier while keeping its workability. Tests have been performed. with $A / E$ relation of 0.6 but compound allow greater water reductions.

In order to improve the general mechanical resistance it is recommended to add Melment L-10 in a $1 \%$, and Sikament $F F$ in a $0.5 \%$ without fibre strengthening.

In order to achieve a greater increase in flection resistance and to improve compressive strength, the addition of $1 \%$ of Melment L-10 with E glass fiber strengthening is recommended. With the 26ESK compound considerable flection resistance increases have been achieved. Standing out the series 17 and 19, with which the greater flection resistance increases have been performed (140-157\%), in relation to the reference series $8 E$.

\section{Conclusions on the addition of fluidifiers to plaster}

The use of fluidifiers as additive in gypsum/plaster, does not help the $A / E$ relation for the same workability.

The main disadvantages of this additives is: it is more expensive and it has a very poor behaviour with fire.

Addition of $3 \%$ is recommended to generally improve the mechanical resistance. 
Si se quiere incrementar considerablemente la resistencia a flexión del material, se recomiendan dosificaciones d el $5 \%$ de aditivo con refuerzo de fibras.

\section{Conclusiónes sobre la adición de plastificantes-aireantes en la escayola}

Facilita la reducción de agua manteniendo la trabajabilidad. Sè ha trabajado con relaciones de $\mathrm{A} / \mathrm{E}=0,6$, pero los compuestos admiten reducciones de agua superiores.

Para aumentar la resistencia en general, se recomienda añadir en la mezcla el 0,5\% de aditivo. Para conseguir incrementos importantes de la resistencia a flexión, se recomienda cualquiera de las dosificaciones de aditivo estudiadas, con un refuerzo de fibra de vidrio $\mathrm{E}$ del $2 \%$.
And of 5\% with fiber strengthening if flection resistance wants to be improved.

\section{Conclusions on the addition of plasticizers-aeraters to plaster}

Its use facilitates the water reduction mantaining its workability. It has been studied with a $A / E$ relation of 0.6 , but the compounds allow greater water reductions.

In relation to mechanical resistance is has been noted that there is a spectacular increase in the flection resistance and a decrease in compression in all the cases studied, except in the series named 6ESKG0.5. Additions of $0.5 \%$ are recommended to achieve increases of flection resistance as well as $2 \%$ E glass fiber strengthening.

\section{BIBLIOGRAFÍA}

(1) R. K. Mishra. "On self-organitation". Edit. H. Haken (1994)

(2) Pliego de recepción de yesos (1985).

(3) M. Fernández Cánovas. Hormigón. Edit. C. O. I. C. C. P. M. (1999)

(4)A. García Santos. "Modelo teórico del comportamiento mecánico del yeso y sus compuestos fibrosos poliméricos". Tesis doctoral(1991) 